\title{
IMPLIKASI PERUBAHAN TARIF DANA REBOISASI DAN PROVISI SUMBER DAYA HUTAN TERHADAP LABA PEMEGANG KONSESI HUTAN DAN PENERIMAAN NEGARA BUKAN PAJAK: STUDI KASUS HUTAN ALAM PRODUKSI DI KALIMANTAN TIMUR, INDONESIA (The Implication of Reforestation Fund and Forest Resource Provision Tariff Changes on Profit of Forest Concessionaire and Non-Tax State Revenue: Case Study of Production Natural Forest in East Kalimantan, Indonesia)
}

\author{
Satria Astana ${ }^{1}$, Soenarno $^{2} \&$ OK Karyono ${ }^{1}$ \\ ${ }^{1}$ Pusat Penelitian dan Pengembangan Perubahan Iklim dan Kebijakan, \\ Jl. Gunung Batu No 5, Bogor, Indonesia, e-mail: astanasatria@yahoo.com., yonokaryono_50@yahoo.com \\ ${ }^{2}$ Pusat Penelitian dan Pengembangan Keteknikan Kehutanan dan Pengolahan Hasil Hutan, Jl. Gunung Batu No. \\ 5 Bogor, Indonesia, e-mail: soenarno@yahoo.co.id
}

Diterima 3 Juni 2014, direvisi 14 Juli 2014 disetujui, 25 Agustus 2014

\begin{abstract}
The decline of natural forest timberproduction has suppressed non-tax revenues (PNBP) of forestry sector. To anticipate further decrease in PNBP the government has been trying to raise tariffs of PSDH and DR. This research aims to study the implications of DR and PSDH tariff increases on profits of forest concessionaires and PNBP of forestry sector, and the potential use of logging waste as an additional source of PNBP. The data collected include: 1) the cost of forest management; 2) the price of logs and 3) logging waste. Data of forest management cost and log price were obtained from the documents and interviews with forest managers, while logging waste data was obtained by measuring in the field. The results of the study reveal that the increases in DR and PSDH tariffs simultaneously would cause the profit of company decreased by 22.3\%, while the PNBP increased by 29.7\%. The study suggest: 1) the policy on increasing DR tariff may be directly applied, while the pricing of logs at the landing site should be based on a rational determination method and 2) increases in DR and PSDH tariffs need to consider the amount of logging waste in the forest.
\end{abstract}

Keywords: Naturalforest, log, DR, PSDH, logging waste.

\begin{abstract}
ABSTRAK
Merosotnya produksi kayu bulat hutan alam menekan penurunan Penerimaan Negara Bukan Pajak (PNBP) sektor kehutanan. Untuk mengantisipasi penurunan PNBP pemerintah berusaha menaikkan besarnya tarif Provisi Sumber Daya Hutan (PSDH) dan Dana Reboisasi (DR). Penelitian ini bertujuan untuk mengkaji implikasi perubahan tarif DR dan PSDH terhadap laba pemegang ijin UPHHK-HA dan PNBP sektor kehutanan, serta potensi pemanfaatan kayu limbah pembalakan sebagai sumber tambahan PNBP sektor kehutanan. Jenis data yang dikumpulkan meliputi: 1) biaya pengelolaan hutan; 2) harga kayu bulat dan 3) limbah pembalakan. Data biaya pengelolaan hutan dan harga kayu bulat diperoleh dari hasil pencatatan dokumen dan wawancara dengan pengelola hutan, sedangkan data limbah pembalakan diperoleh berdasarkan pengukuran di lapangan. Hasil kajian menunjukkan perubahan tarif DR dan PSDH secara berbarengan menyebabkan perolehan laba perusahaan menurun sebesar 22,3\%, sedangkan perolehan PNBP meningkat sebesar 29,7\%. Hasil kajian menyarankan: 1) kebijakan kenaikan tarif DR dapat langsung diberlakukan, sementara penetapan harga kayu bulat di Tempat Pengumpulan Kayu (TPn) perlu didasarkan pada suatu metode penetapan yang rasional dan 2) perubahan tarif DR dan PSDH perlu mempertimbangkan besarnya limbah pembalakan di hutan.
\end{abstract}

Kata kunci: Hutan alam, kayu bulat, DR, PSDH, limbah pembalakan.

\section{PENDAHULUAN}

Peraturan Pemerintah (PP) Nomor 59 tahun 1998 tentang Tarif Atas Jenis PNBP pada
Departemen Kehutanan dan Perkebunan telah direvisi beberapa kali. Pertama adalah dengan PP Nomor 74 tahun 1999 (revisi pertama) dan kedua adalah dengan PP Nomor 92 tahun 1999 (revisi 
kedua). Berdasarkan PP Nomor 74 tahun 1999 tentang Perubahan PP Nomor 59 tahun 1998, tarif Provisi Sumberdaya Hutan (PSDH) diubah (PP Nomor 74 tahun 1999 Pasal 1). Besarnya pungutan PSDH untuk kayu hutan alam diubah, semula 6\% dari harga patokan menjadi 10\% dari harga patokan, sedangkan berdasarkan PP Nomor 92 tahun 1999 tentang Perubahan Kedua PP 59 tahun 1998, pungutan Dana Reboisasi (DR) dimasukkan ke dalam ketentuan PP Nomor 92 tahun 1999 ini (sebelumnya penyetoran pungutan DR diatur oleh PP Nomor 22 tahun 1997 tentang Jenis dan Penyetoran PNBP (Pasal 4), yang telah diubah dengan PP Nomor 52 tahun 1998). Besarnya pungutan DR untuk kelompok jenis meranti adalah USD 13-16 per $\mathrm{m}^{3}$, kelompok jenis rimba campuran adalah USD 10,5-13 per $\mathrm{m}^{3}$, kelompok jenis kayu indah adalah USD 16-20 per $\mathrm{m}^{3}$ dan limbah pembalakan serta bahan baku serpih adalah USD 2 per $\mathrm{m}^{3}$. Merosotnya produksi kayu bulat hutan alam mengacam penurunan PNBP sektor kehutanan. Untuk mengantisipasi penurunan PNBP, pemerintah kemudian berusaha menaikkan besarnya tarif PSDH dan DR.

Dalam revisi Peraturan Pemerintah Nomor 59 tahun 1998 tentang Tarif Atas Jenis PNBP yang berlaku pada Departemen Kehutanan dan Perkebunan, yang sedang diusulkan, Kementerian Kehutanan (Kemenhut) mengusulkan kenaikan tarif DR untuk kayu bulat berdiameter di atas $49 \mathrm{~cm}$ sebesar USD 0,5 per $\mathrm{m}^{3}$ merata untuk seluruh jenis dan wilayah, sedangkan kayu berdimeter 30-49 cm tetap. Usulan perubahan ini telah disetujui oleh kementerian yang terkait termasuk Kementerian Keuangan (Kemenkeu), Kementerian Perdagangan (Kemendag) serta Kementerian Hukum dan Hak Asasi Manusia (Kemenkumham). Berdasarkan kesepakatan yang telah dicapai, draft revisi PP Nomor 59 tahun 1998 kemudian diajukan ke Sekretariat Negara (Sekneg) untuk disahkan oleh pemerintah dan diumumkan ke masyarakat dalam Lembaran Negara. Namun revisi RPP tersebut dikembalikan oleh Setneg kepada Kemenhut untuk ditinjau kembali karena Asosiasi Pengusaha Hutan Indonesia (APHI) masih keberatan dengan perubahan tersebut dengan alasan kenaikannya memberatkan pengusaha hutan.

Pada 9 April 2013 Ditjen Bina Usaha Kehutanan (BUK) menyelenggarakan pertemuan dengan stakeholders termasuk Pusat Litbang Perubahan Iklim dan Kebijakan (Puspijak) mendiskusikan solusi untuk mengatasi jalan buntu mengenai perubahan tarif DR dan PSDH. Hasil pertemuan menyarankan perlu pengkajian ulang terhadap besarnya tarif DR, sedangkan mengenai harga patokan sebagai dasar pengenaan iuran kehutanan (PSDH dan Pengganti Nilai Tegakan/PNT), Ditjen BUK (2013) melaporkan telah disepakati bahwa penetapan harga patokan yang sebelumnya ditetapkan oleh Kemendag diubah ditetapkan oleh Kemenhut. Berdasarkan Kemendag, harga patokan dihitung dari harga rataan tertimbang kayu bulat di pasar domestik dan internasional, sedangkan berdasarkan Kemenhut, harga patokan dihitung dari harga rataan kayu bulat di TPn untuk hutan alam, harga rataan tegakan pada Hutan Tanaman Industri (HTI), dan harga rataan di Tempat Pengumpulan Sementara (TPS) untuk hasil hutan bukan kayu. Perubahan-perubahan yang terjadi menimbulkan kontroversi di kalangan stakeholders.

Usulan revisi tarif DR kayu bulat berdasarkan kelas diameter ternyata tidak disetujui oleh APHI. APHI berpendapat kenaikan tarif DR sebesar USD 0,5 per $\mathrm{m}^{3}$ untuk seluruh kelompok jenis kayu bulat berdiameter di atas $49 \mathrm{~cm}$ dan tarif DR untuk kayu bulat berdiameter 30-49 cm kelompok jenis meranti antara USD 13-16 per $\mathrm{m}^{3}$ serta kelompok jenis rimba campuran antara USD 10,513 per $\mathrm{m}^{3}$ dipandang memberatkan pengusaha hutan alam, dengan alasan karena harga kayu bulat di pasar dalam negeri yang rendah. Merujuk hasil kajian Kartodihardjo \& Soedomo (2013), APHI mengusulkan tarif DR kayu bulat berdiameter 30$49 \mathrm{~cm}$ antara USD 6-7 per $\mathrm{m}^{3}$ sesuai dengan jenis dan sebaran wilayah, sedangkan tarif DR kayu bulat berdiameter di atas $49 \mathrm{~cm}$ tidak dinaikkan. Namun usulan ini masih belum disetujui, karena PNBP dari sektor kehutanan setiap tahun dituntut meningkat oleh Dewan Perwakilan Rakyat. Dengan demikian inti persoalannya adalah bagaimana menetapkan tarif DR yang di satu sisi tidak mengguncangkan laba pengusaha hutan dan di sisi lain penerimaan PNBP dapat ditingkatkan? Pada tanggal 18 Juni 2013 pembahasan bersama Dirjen BUK dilaksanakan di Gedung Manggala Wanabhakti. Berdasarkan hasil pembahasan, Dirjen BUK memutuskan bahwa tarif DR untuk kayu bulat yang berdiameter di atas $49 \mathrm{~cm}$ dinaikkan sebesar USD 0,5 per $\mathrm{m}^{3}$, sedangkan kayu bulat yang berdiameter antara 30-49 cm diturunkan antara USD 6-7 per $\mathrm{m}^{3}$. 
Persoalan penetapan tarifDR dan harga patokan PSDH yang tidak mengguncangkan laba pengusaha hutan memerlukan analisis perilaku biaya produksi dan harga kayu bulat, sedangkan peningkatan PNBP sektor kehutanan memerlukan informasi mengenai potensi pengurangan limbah pembalakan serta besarnya kontribusi DR dan PSDH yang dikenakan. Pungutan DR didasarkan pada kelas diameter, sedangkan PSDH pada harga patokan yang ditetapkan di TPn (untuk kayu hutan alam) dan di hutan (untuk kayu hutan tanaman). Dalam per temuan tanggal 18 Juni 2013 usulan APHI adalah: tarif DR untuk kayu bulat yang berdiameter di atas (>) $50 \mathrm{~cm}$ dinaikkan sebesar USD 0,5 per $\mathrm{m}^{3}$, sedangkan kayu bulat yang berdiameter antara 40$49 \mathrm{~cm}$ antara USD 6-7 per $\mathrm{m}^{3}$. Keputusan ini didasarkan pada teori bahwa pengenaan tarif yang tinggi akan mengurangi produksi dan sebaliknya pengenaan tarif yang rendah akan meningkatkan produksi. Dengan demikian, produksi kayu bulat yang berdiameter di atas $50 \mathrm{~cm}$ diharapkan akan menurun dan sebaliknya produksi kayu bulat yang berdiameter 40-49 cm diharapkan meningkat, meskipun implikasi terhadap produksi kayu bulat yang berdiameter 30-39 cm belum diketahui.

Untuk memahami implikasi perubahan tarif DR dan PSDH terhadap perolehan laba pemegang ijin UPHHK-HA dan PNBP, tiga hipotesis diuji. Pertama, perubahan tarif DR (naik sebesar USD 0,5 per $\mathrm{m}^{3}$ untuk kayu bulat berdiamater di atas 49 $\mathrm{cm})$ dan PSDH (10\% dari harga patokan di TPn) tidak mengguncang laba pengusaha hutan (pemegang ijin UPHHK-HA). Kedua, penerimaan PNBP dari PSDH yang ditetapkan sebesar 10\% dari harga patokan di TPn lebih sensitif dibanding kenaikan tarif DR sebesar USD 0,50 per $\mathrm{m}^{3}$ untuk kayu bulat yang berdiameter di atas $49 \mathrm{~cm}$. Ketiga, pemanfaatan limbah kayu pembalakan berpotensi menyumbang PNBP sektor kehutanan. Penelitian ini bertujuan untuk mengkaji: 1) implikasi perubahan tarif DR dan PSDH terhadap laba pemegang ijin UPHHK-HA dan PNBP sektor kehutanan dan 2) potensi PNBP dari pemanfaatan limbah kayu pembalakan.

\section{METODE PENELITIAN}

\section{A. Lokasi dan Waktu Penelitian}

Obyek hutan yang dikaji adalah hutan negara yaitu hutan alam produksi yang dikelola berdasarkan ijin UPHHK-HA. Idealnya penelitian dilakukan pada beberapa contoh pemegang konsesi hutan sehingga kesimpulan dan implikasi yang lebih berlaku umum dapat diperoleh. Namun dalam penelitian ini kondisi ideal tersebut tidak diperoleh. Sebagai ganti, penelitian dilakukan pada satu contoh pemegang konsesi sebagai studi kasus. Penelitian dilaksanakan di areal hutan pemegang ijin UPHHK-HA contoh di Kalimantan Timur pada bulan Agustus 2013 (nama perusahaan tidak dicantumkan atas permintaan perusahaan yang bersangkutan). Luas areal ijin UPHHK-HA contoh awalnya (tahun 1970) adalah 125.000 ha namun kemudian pada tahun 2000 mengalami pengurangan menjadi seluas $97.690 \mathrm{ha}$. Sejak tahun 2010 luas arealnya berkurang sebesar 4.165 ha menjadi seluas 93.425 ha.

\section{B. Kerangka Analisis}

Secara luas, empat tujuan kebijakan ekonomi pungutan di bidang kehutanan adalah: 1) penerimaan keuangan bagi pemerintah; 2) kepraktisan dan biaya administrasi; 3) efisiensi ekonomi dalam pemanfaatan dan manajemen hutan dan 4) pemerataan dalam distribusi dampak ekonomi, penerimaan dan penghasilan (Gray, 1983). Kebijakan yang dianalisis adalah kebijakan pencapaian penerimaan keuangan bagi pemerintah. Diketahui bahwa eksploitasi sumber daya alam seperti bijih besi, ikan atau kayu cenderung menghasilkan rente ekonomi (Karsenty, 2010). Dalam UU Nomor 20 tahun 1997 tentang Penerimaan Negara Bukan Pajak (PNBP), PNBP mencakup penerimaan yang diperoleh dari kegiatan pemanfaatan sumber daya alam (Pasal 2 Ayat 1 b). Hutan alam produksi merupakan sumber daya alam dan pemanfaatannya dikenakan pungutan bukan pa-jak. Namun penetapan tarif atas jenis PNBP harus memperhatikan: 1) dampak pengenaan terhadap masyarakat dan kegiatan usahanya; 2) biaya penyelenggaraan kegiatan pemerintah sehubungan dengan jenis PNBP yang bersangkutan dan 3) aspek keadilan dalam pengenaan beban kepada masyarakat (UU Nomor 20 tahun 1997 Pasal 3 Ayat 1). Pemanfaatan hutan alam produksi yang dikaji adalah usaha pemanfaatan hutan, dan tarif PNBP yang dikaji adalah besarnya tarif PSDH dan DR yang dikenakan. 
DR awalnya dinamakan Dana Jaminan Reboisasi (DJR) (Keppres Nomor 35 tahun 1980). Sesuai namanya, DJR dipungut berdasarkan argumen sebagai dana jaminan dari pemegang ijin UPHHKHA agar melaksanakan kewajiban mereboisasi hutan yang telah ditebang sehingga setelah 35 tahun dapat dipanen kembali. Jika pemegang ijin UPHHK melaksanakan kewajiban tersebut, maka DJR yang dipungut oleh pemerintah dikembalikan kepada pemegang ijin setelah melalui penilaian oleh pemerintah. Dalam praktiknya, terdapat keraguan bagi pemegang ijin UPHHK, yang diduga karena pada saat itu sistem dan standar penilaian kinerja PHAPL sebagai dasar pengembalian DJR belum sejelas sekarang, misalnya menggunakan sistem dan standar PHAPL skema mandatory atau voluntary. Dengan kata lain, pemegang $\mathrm{HPH}$ menafsirkan DJR sebagai jaminan pelaksanaan reboisasi sehingga tidak perlu melakukan reboisasi di areal bekas tebangan dan lahan kritis (Saputra, 1995). Pemegang ijin UPHHK saat itu diduga meyakini lebih menguntungkan tidak mengambil kembali DJR, sementara pemerintah diduga memandang penerimaan DJR yang semakin membesar lebih efektif digunakan untuk mengatasi fiscal deficit. Pungutan DJR akhirnya diubah statusnya menjadi DR (Keppres Nomor 29 tahun 1989) tanpa mempertimbangkan ide awal DJR yang bertujuan untuk menjamin kelestarian hutan yang ditebang. Dengan perubahan ini, pemerintah menghendaki pungutan royalty bukan sebagai jaminan reboisasi tetapi sebagai pembayaran wajib reboisasi bagi pemegang $\mathrm{HPH}$, sementara pemeliharaan hutan tetap harus dilaksanakan sesuai ketentuan TPTI (Saputra, 1995). Soedomo (2013) memandang DR juga bukan sebagai jaminan kinerja (performance bond).

Pada awalnya PSDH dinamakan Iuran Hasil Hutan (IHH) (PP Nomor 22 tahun 1997 tentang Jenis dan Penyetoran Penerimaan Negara Bukan Pajak: Lampiran IIA Angka 9). IHH kemudian diubah menjadi PSDH (Pasal I PP Nomor 52 tahun 1998 tentang Perubahan PP Nomor 22 tahun 1997 tentang Jenis dan Penyetoran PNBP). Di era pemerintahan Soekarno dikenal istilah cukai hasil hutan (PP Nomor 64 tahun 1957 Pasal 10 Ayat 5 Sub-ayat 2), yang maksudnya sama dengan PSDH (Greenomics Indonesia \& Indonesia Corruption Watch, 2004). Dengan PP Nomor 59 tahun 1998, regulasi pungutan PSDH mengalami tiga perubahan mendasar. Pertama adalah Menteri Perindustrian dan Perdagangan menetapkan harga patokan berdasarkan harga jual rataan tertimbang hasil hutan yang berlaku di pasar domestik dan atau internasional (PP Nomor 59 tahun 1998 Pasal 3). Kedua adalah tata cara pengenaan, pemungutan, dan penyetoran PNBP diatur oleh Menteri Keuangan setelah mendengar Pertimbangan Menteri Kehutanan dan Perkebunan (PP Nomor 59 tahun 1998 Pasal 4). Ketiga adalah ketentuan Pasal 5 PP Nomor 51 tahun 1998 tentang Provisi Sumber Daya Hutan dinyatakan tidak berlaku (PP Nomor 59 tahun 1998 Pasal 5).

Terkait upaya menaikkan PNBP sektor kehutanan, dua isu diperdebatkan. Pertama, harga patokan kayu bulat untuk perhitungan tarif PSDH berdasarkan Permendag Nomor 8/M-DAG/ PER/2/2007 lebih rendah dibanding biaya produksi kayu bulat (Astana \& Siran, 2011). Kedua, harga patokan didasarkan pada harga rataan tertimbang di pasar domestik dan internasional. Harga kayu bulat di logpond penjualan tahun 1998 ketika ekspor kayu bulat dibuka adalah Rp 925.000 per $\mathrm{m}^{3}$, sedangkan ketika ekspor kayu bulat kemudian dilarang kembali tahun 2001 harganya menurun tajam menjadi Rp 550.000 per $\mathrm{m}^{3}$ (Astana, 2003). Penetapan harga rataan tertimbang di pasar domestik dan internasional tidak relevan lagi, karena kebijakan ekspor kayu bulat telah dihapuskan. Ini mendorong revisi ketiga terhadap PP Nomor 59 tahun 1998. Terkait dengan penetapan tarif PSDH, Kemenhut mengusulkan harga patokan ditetapkan oleh Kemenhut berdasarkan harga pasar di TPn (Direktorat BIKPHH, 2013). Terkait penetapan tarif DR, Kemenhut mengusulkan didasarkan pada kelas diameter kayu bulat. Tarif DR untuk kayu bulat yang sebelumnya tidak dibedakan berdasarkan kelas diameter diubah menjadi dibedakan ke dalam kelas diameter 30-49 $\mathrm{cm}$ dan di atas $49 \mathrm{~cm}$ (Direktorat BIKPHH, 2013).

Perubahan tarif DR dan PSDH akan menimbulkan persoalan, yang dapat dibedakan ke dalam dua kategori. Pertama adalah persoalan tradeoff antara laba pengusaha dan PNBP pemerintah. Besarnya pungutan berimplikasi terhadap PNBP di satu sisi dan di sisi lain terhadap laba pemegang ijin UPHHK dalam hutan alam (UPHHK-HA). Permasalahannya muncul ketika besarnya pungutan yang dikenakan di satu sisi dapat meningkatkan PNBP kehutanan namun di sisi lain menurunkan laba pemegang ijin UPHHK-HA atau sebaliknya. Ini merupakan aspek keadilan dalam pengenaan 
beban kepada masyarakat (amanat UU Nomor 20 tahun 1997 tentang PNBP: Pasal 3 Ayat 1). Kedua adalah persoalan legalitas dan metode perhitungan PSDH dan DR. Permasalahan legalitas PSDH dan DR berkaitan dengan tujuan dan metode perhitungan masing-masing pungutan yang dikenakan. Permasalahannya muncul ketika kenaikannya tidak memiliki dasar perhitungan yang jelas dan diterima oleh pihak-pihak yang berkepentingan. Ini merupakan aspek legal pengenaan pungutan PSDH dan DR (amanat UU 41 tentang Kehutanan tahun 1999: Pasal 35 Ayat 1).

Gambar 1 menjelaskan implikasi perubahan tarif DR dan PSDH terhadap Penerimaan Negara Bukan Pajak.

Pada Gambar 1 diketahui bahwa besarnya PNBP sektor kehutanan bersumber setidaknya dari dua jenis pungutan bukan pajak, yaitu: 1) penerimaan PSDH dan 2) penerimaan DR. Sumber penerimaan lain seperti IUPHHK-HA/HT/HTR tidak dimasukkan karena porsinya relatif kecil. Besarnya penerimaan PSDH dipengaruhi oleh besarnya tarif PSDH yang dikenakan dan harga kayu bulat di pasar serta produksi kayu bulat, sedangkan besarnya penerimaan DR dipengaruhi oleh besarnya tarif DR yang dikenakan dan produksi kayu bulat; harga kayu bulat tidak berpengaruh karena DR ditetapkan per $\mathrm{m}^{3}$ kayu bulat. Selain melaui tarif DR dan PSDH, dari Gambar 1 diketahui bahwa peningkatan PNBP sektor kehutanan juga dapat dilakukan melalui pemanfaatan limbah pembalakan.

\section{Jenis dan Pengumpulan Data}

Jenis data yang dikumpulkan meliputi: 1) biaya pengelolaan hutan; 2) harga kayu bulat dan 3) limbah pembalakan. Data biaya pengelolaan hutan dan harga kayu bulat diperoleh dari hasil pencatatan dokumen dan wawancara dengan pengelola hutan, sedangkan data limbah pembalakan diperoleh berdasarkan pengukuran di lapangan.

\section{Pengolahan dan Analisis Data}

Kegiatan kajian meliputi: 1) analisis biaya pengelolaan hutan; 2) analisis harga kayu bulat dan 3) analisis limbah pembalakan.

\section{Biaya Pengelolaan Hutan}

Untuk melihat pengaruh besarnya pungutan PSDH dan DR terhadap perbaikan stok hutan dan lingkungan serta sosial, biaya pengelolaan hutan dipisahkan ke dalam tujuh kelompok biaya, yaitu: 1) biaya produksi; 2) biaya perbaikan stok hutan; 3 ) biaya kewajiban kepada negara; 4) biaya kelola sosial; 5) biaya kelola lingkungan; 6) biaya sarpras dan 7) biaya umum dan administrasi.

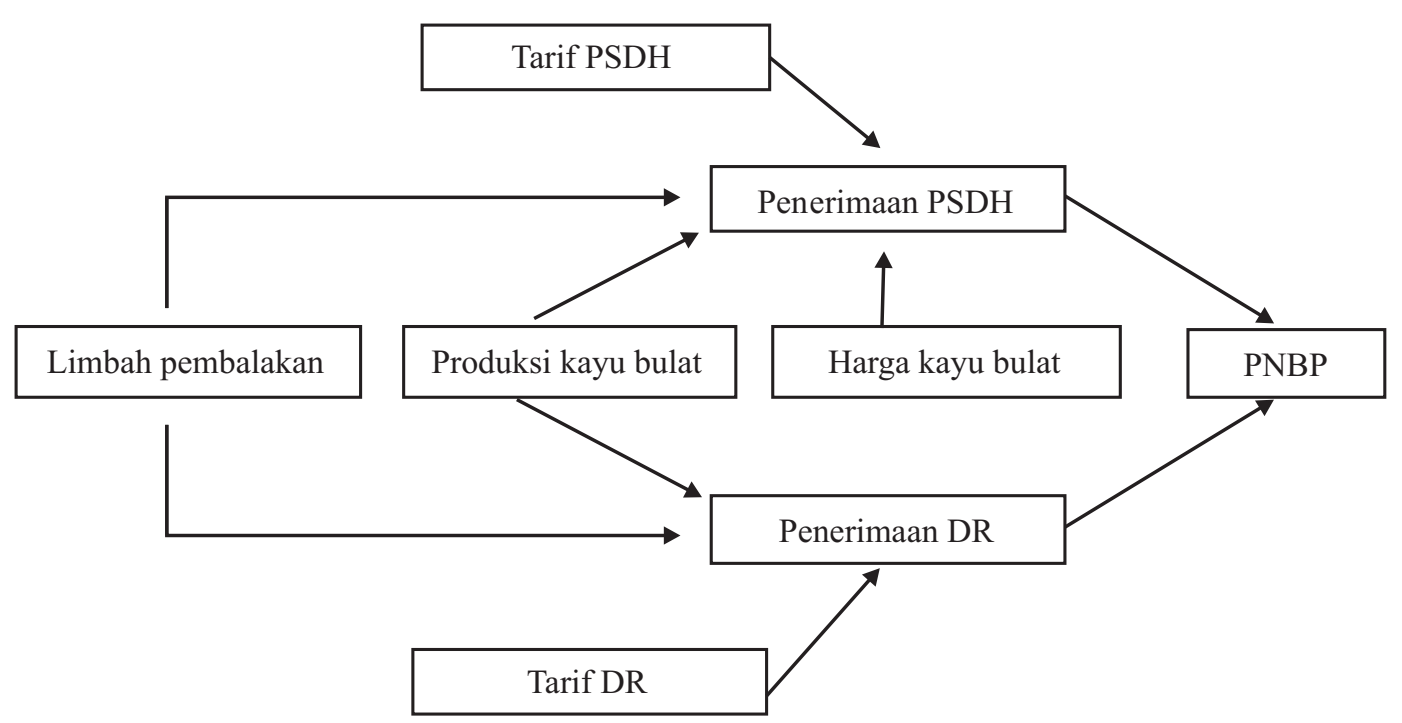

Gambar 1. Kerangka kajian implikasi perubahan tarif PSDH dan DR terhadap Penerimaan Negara Bukan Pajak.

Figure 1. Study framework of implications of PSDH and DR tariff changes on non-tax state revenue. 
Biaya produksi kayu bulat meliputi: 1) biaya perencanaan hutan dan 2) pemungutan hasil hutan, sedangkan biaya perbaikan stok hutan meliputi: 1) biaya penanaman; 2) biaya pemeliharaan dan pembinaan hutan serta 3) biaya pengendalian kebakaran dan pengamanan hutan.

Biaya sebagai kewajiban kepada negara meliputi: 1) IIUPHHK-HA; 2) PSDH; 3) DR dan 4) retribusi daerah, sedangkan biaya kelola lingkungan dan sosial antara lain meliputi: 1) PMDH; 2) pemantauan dan pengelolaan lingkungan; 3) plasma nutfah; 4) litbang; 5) SDM; 6) Dana Kompensasi Desa dan amortisasi.

Biaya pembangunan sarpras antara lain meliputi: 1) pemeliharaan bangunan dan fasilitas jalan dan jembatan serta 2) penyusutan bangunan dan fasilitas, jalan, jembatan, peralatan, sedangkan biaya umum dan administrasi antara lain meliputi: gaji karyawan, perjalanan dinas, pengobatan, pemeliharaan dan penyusutan bangunan dan kendaraan serta inventaris kantor, pendidikan dan pelatihan.

\section{Harga Kayu Bulat}

Harga kayu bulat dibedakan ke dalam tiga gerbang penerimaan: 1) gerbang TPn; 2) gerbang logpond/logyard (TPK) dan 3) gerbang industri. Harga di gerbang TPn adalah harga kayu bulat ketika kayu bulat hasil penebangan telah ditempatkan di TPn. Besarnya harga ini adalah biaya tetap per $\mathrm{m}^{3}$ ditambah biaya variabel penebangan dan pengangkutan sampai di TPn ditambah margin keuntungan, sedangkan harga di gerbang logpond/logyard adalah harga kayu bulat ketika berada di logpond/logyard. Besarnya harga ini adalah harga di TPn ditambah biaya pengangkutan dari TPn ke logpond/ logyard. Harga di gerbang industri adalah harga kayu bulat di lokasi industri. Besarnya harga ini adalah harga di logpond/logyard ditambah biaya pengangkutan dari logpond/ logyard ke industri.

\section{Limbah Pembalakan}

Berdasarkan sumbernya, limbah pembalakan dibedakan ke dalam dua kelompok, yaitu: 1) limbah kayu dari batang bebas cabang (BBC) dan 2) limbah kayu dari batang di atas BBC. Limbah kayu dari BBC dibedakan ke dalam dua golongan, yaitu: 1) limbah pangkal dan 2) limbah ujung, sedangkan limbah dari batang di atas BBC dinamakan limbah ujung.

\section{HASIL DAN PEMBAHASAN}

\section{A. Implikasi Perubahan Tarif DR dan PSDH terhadap Laba Pemegang Ijin UPHHK- HA}

Sebagai royalty, DR awalnya dinamakan DJR yang dikenakan kepada pemegang HPH melalui Keppres Nomor 35 tahun 1980 pada setiap m ${ }^{3}$ kayu bulat yang diproduksi. Dalam hal ini, pemegang HPH menafsirkan DJR sebagai jaminan pelaksanaan reboisasi sehingga tidak perlu melakukan reboisasi sendiri di areal bekas tebangan dan lahan kritis (Saputra, 1995). Namun sejak tahun 1989, DJR diubah menjadi DR melalui Keppres Nomor 29 tahun 1989. Dengan perubahan ini, pemerintah menghendaki pungutan royalty bukan sebagai jaminan reboisasi tetapi sebagai pembayaran wajib reboisasi bagi pemegang $\mathrm{HPH}$, sementara pemeliharaan hutan tetap harus dilaksanakan sesuai ketentuan TPTI (Saputra, 1995).

Hasil analisis biaya pengelolaan hutan kasus perusahaan pemegang ijin IUPHHK-HA contoh di Kalimantan Timur disajikan pada Tabel 1. Pada Tabel 1 terlihat bahwa dari total biaya pengelolaan hutan, biaya terbesar adalah biaya sarpras $(31,3 \%)$, kemudian disusul oleh biaya kewajiban kepada negara $(25,7 \%)$, biaya produksi kayu bulat $(23,2 \%)$ dan biaya umum dan administrasi (16,3\%). Biaya produksi kayu bulat didominasi oleh biaya pemungutan hasil hutan $(20,6 \%)$, sedangkan kewajiban kepada negara oleh pungutan DR $(16,4 \%)$. Biaya terkecil adalah biaya kelola lingkungan dan sosial $(1,2 \%)$, kemudian disusul oleh biaya perbaikan stok hutan $(2,3 \%)$.

Tabel 2 menyajikan perubahan tarif DR. Pada Tabel 2 terlihat sebelum perubahan, besarnya tarif DR wilayah Kalimantan (Kalimantan Timur) dan Maluku adalah USD 16 per $\mathrm{m}^{3}$ untuk kelompok jenis meranti dan USD 13 per $\mathrm{m}^{3}$ untuk kelompok jenis campuran tanpa pembedaan kelas diameter. Setelah perubahan, besarnya tarif DR wilayah Kalimantan (Kalimantan Timur) dan Maluku adalah USD 16 per $\mathrm{m}^{3}$ untuk kelompok jenis meranti berdiameter 39-49 $\mathrm{cm}$ dan USD 16,5 per $\mathrm{m}^{3}$ untuk kelompok jenis meranti berdiameter di atas $49 \mathrm{~cm}$. Untuk kelompok jenis campuran adalah USD 13 per $\mathrm{m}^{3}$ untuk kayu bulat berdiamater 39-49 $\mathrm{cm}$ dan USD 13,5 per $\mathrm{m}^{3}$ untuk yang berdiameter di atas $49 \mathrm{~cm}$. Implikasi 
perubahan tarif DR terhadap laba perusahaan contoh disajikan pada Tabel 3. Pada Tabel 3 terlihat bahwa perubahan tarif DR yang terjadi diharapkan akan menyebabkan kewajiban kepada negara meningkat dari Rp 243.112 menjadi Rp 248.862 atau 2,4\%, biaya pengelolaan hutan meningkat dari Rp 946.410 menjadi Rp 952.160 atau 0,6 \% dan konsekuensinya perolehan laba perusahaan contoh menurun dari Rp 181.908 per $\mathrm{m}^{3}$ menjadi Rp 176.158 per $\mathrm{m}^{3}$ atau menurun $3,2 \%$.

Tabel 1. Komponen biaya pengelolaan hutan alam untuk perusahaan contoh di Kalimantan Timur.

Table 1. Cost component of natural forest management for sample company in East Kalimantan.

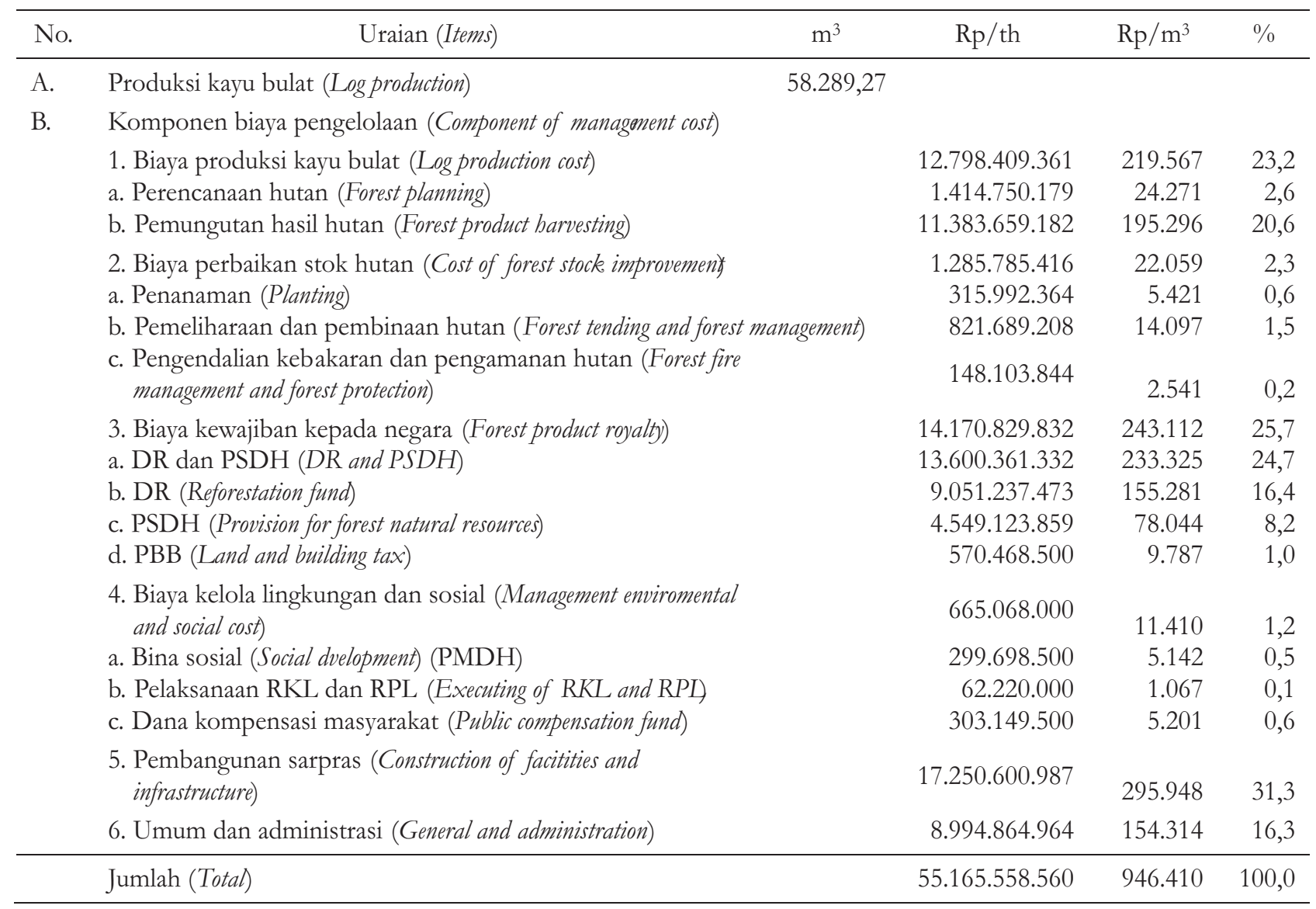

Tabel 2. Tarif DR sebelum dan sesudah usulan perubahan PP59/1998 wilayah Kalimantan dan Maluku. Table 2. DR tariff before and after PP59/1998 change for Kalimantan and Maluku areas.

\begin{tabular}{|c|c|c|c|c|}
\hline \multirow[b]{2}{*}{ No. } & \multirow[b]{2}{*}{ Kelompok jenis kayu (Species group) } & \multicolumn{3}{|c|}{ Tarif DR berdasarkan (DR tariff based on) PP59/1998 } \\
\hline & & $\begin{array}{c}\text { Sebelum perubahan (Before } \\
\text { changing)* } \\
\left(\mathrm{USD} / \mathrm{m}^{3}\right)\end{array}$ & $\begin{array}{c}\text { Setelah perubahan (After } \\
\text { changing)** } \\
\left(\mathrm{USD} / \mathrm{m}^{3}\right)\end{array}$ & $\begin{array}{c}\% \text { perubahan } \\
\text { (Change) }\end{array}$ \\
\hline 1 & $\begin{array}{l}\text { Meranti (Dipterocar } p) \\
30 \mathrm{~cm}<\varnothing<49 \mathrm{~cm} \\
\varnothing>49 \mathrm{~cm}\end{array}$ & $\begin{array}{l}16,00 \\
16,00\end{array}$ & $\begin{array}{l}16,00 \\
16,50\end{array}$ & $\begin{array}{c}0 \\
3,1\end{array}$ \\
\hline 2 & $\begin{array}{l}\text { Rimba campuran (Mixed wood) } \\
30 \mathrm{~cm}<\varnothing<49 \mathrm{~cm} \\
\varnothing>49 \mathrm{~cm}\end{array}$ & $\begin{array}{l}13,00 \\
13,00\end{array}$ & $\begin{array}{l}13,00 \\
13,50\end{array}$ & $\begin{array}{c}0 \\
3,8\end{array}$ \\
\hline
\end{tabular}

Sumber (Source): *PP Nomor 59/1998; **PP Nomor 12/2014. 
Tabel 3. Implikasi perubahan tarif DR terhadap laba perusahaan contoh di Kalimantan Timur. Table 3. Implication of DR tariff change on profit of sample company in East Kalimantan.

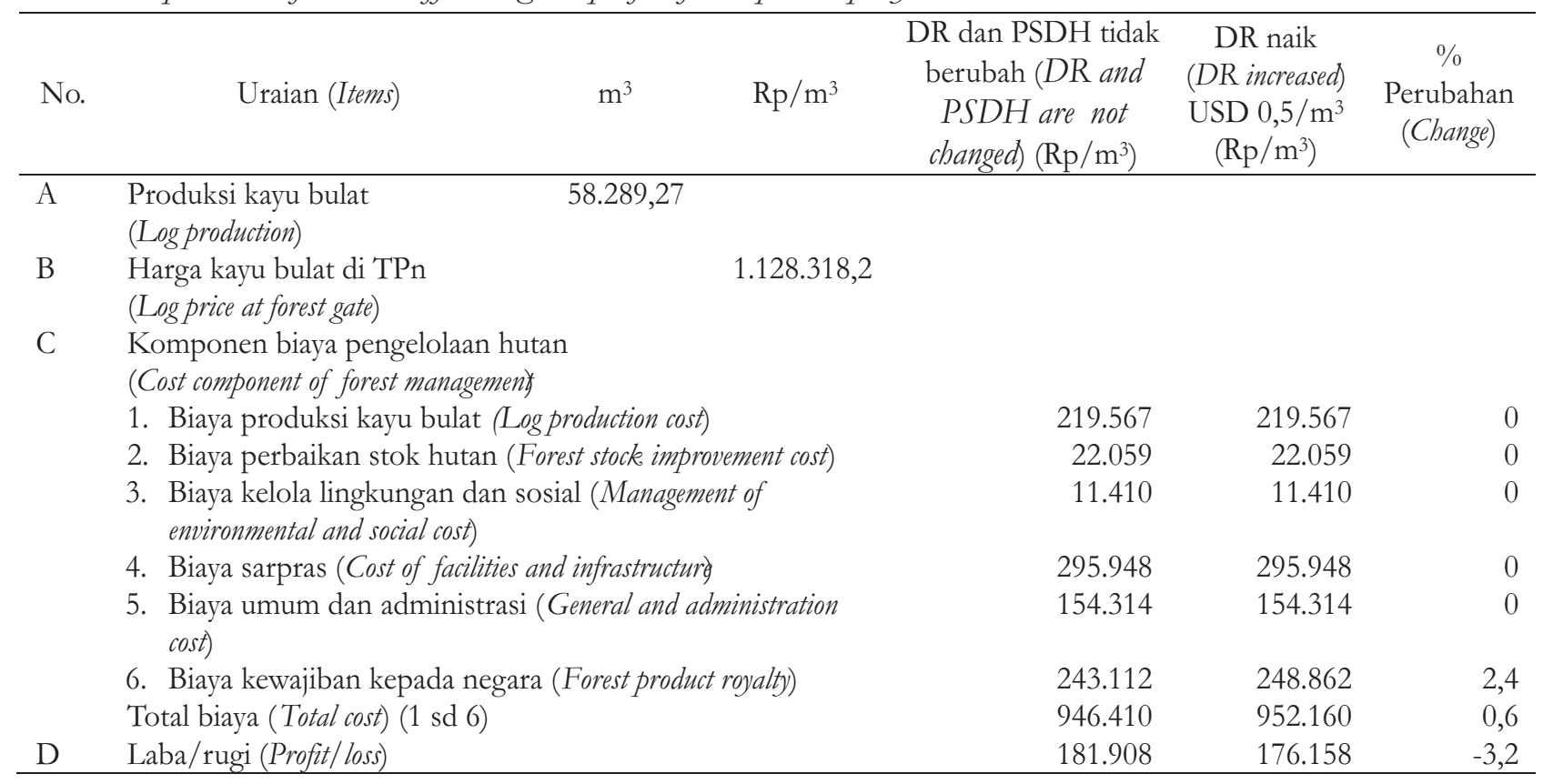

Tabel 4. Tarif PSDH sebelum dan sesudah usulan perubahan PP59/1998 wilayah Kalimantan dan Maluku. Table 4. PSDH tarrif before and after PP59/1998 change for Kalimantan \& Maluku areas.

\begin{tabular}{|c|c|c|c|c|}
\hline \multirow[b]{2}{*}{ No. } & \multirow[b]{2}{*}{$\begin{array}{l}\text { Kelompok jenis kayu } \\
\text { (Species group) }\end{array}$} & \multicolumn{3}{|c|}{ Tarif PSDH berdasarkan (PSDH tariff lased on) PP59/1998 } \\
\hline & & $\begin{array}{l}\text { Sebelum perubahan } \\
\text { (Before changing)* }\end{array}$ & $\begin{array}{l}\text { Setelah perubahan } \\
(\text { After changing) } * *\end{array}$ & $\begin{array}{c}\% \text { perubahan } \\
\text { (Change) }\end{array}$ \\
\hline \multirow[t]{3}{*}{1} & Meranti (Dipterocarp) & & & \\
\hline & $30 \mathrm{~cm}<\varnothing<49 \mathrm{~cm}$ & $10 \% x R p 600.000$ & 10\%xharga di TPn & na \\
\hline & $\varnothing>49 \mathrm{~cm}$ & $10 \% x \operatorname{Rp} 600.000$ & 10\%xharga di TPn & na \\
\hline \multirow[t]{3}{*}{2} & Rimba campuran (Mixed wood) & & & \\
\hline & $30 \mathrm{~cm}<\varnothing<49 \mathrm{~cm}$ & $10 \% x \operatorname{Rp} 360.000$ & 10\%xharga di TPn & na \\
\hline & $\varnothing>49 \mathrm{~cm}$ & $10 \% x \operatorname{Rp} 360.000$ & 10\%xharga di TPn & na \\
\hline
\end{tabular}

Keterangan (Remark): na, not applicable.

Sumber (Source): *PP Nomor 59/1998; Permendag 8/M-DAG/PER/2/2007; **PP Nomor 12/2014.

Tabel 4 menyajikan tarif PSDH sebelum dan sesudah perubahan. Pada Tabel 4 terlihat sebelum perubahan, besarnya tarif PSDH dihitung berdasarkan persentase $(10 \%)$ terhadap harga patokan yang ditetapkan oleh Kemendag (Permendag Nomor 8/M-DAG/PER/2/2007 tentang Penetapan Harga Patokan untuk Perhitungan PSDH Kayu dan Bukan Kayu). Setelah perubahan, besarnya tarif PSDH dihitung berdasarkan persentase (10\%) terhadap harga patokan yang ditetapkan oleh Kemenhut di TPn. Tabel 5 menyajikan implikasi perubahan tarif PSDH terhadap laba perusahaan contoh. Pada Tabel 5 terlihat perubahan tarif PSDH yang terjadi dapat diharapkan akan menyebabkan kewajiban kepada negara meningkat dari $\mathrm{Rp} 243.112$ per $\mathrm{m}^{3}$ menjadi Rp 277.900 per $\mathrm{m}^{3}$ atau 14,3\%, biaya pengelolaan hutan meningkat dari Rp 946.410 per $\mathrm{m}^{3}$ menjadi $\mathrm{Rp} 981.198$ per $\mathrm{m}^{3}$ atau 3,7\% dan konsekuensinya perolehan laba perusahaan contoh menurun dari $\mathrm{Rp} 181.908$ per $\mathrm{m}^{3}$ menjadi Rp 147.120 per $^{3}$ atau $19,1 \%$.

Implikasi perubahan tarif DR dan PSDH terhadap laba perusahaan contoh disajikan pada Tabel 6. Pada Tabel 6 terlihat bahwa perubahan (kenaikan) tarif DR dan PSDH secara berbarengan akan menyebabkan kewajiban kepada negara meningkat dari Rp 243.112 per $\mathrm{m}^{3}$ menjadi Rp 283.650 per $\mathrm{m}^{3}$ atau $16,7 \%$, biaya pengelolaan hutan meningkat dari Rp 946.410 per $\mathrm{m}^{3}$ menjadi 
Rp 986.948 per $\mathrm{m}^{3}$ atau 4,3\% dan konsekuensinya perolehan laba perusa-haan contoh menurun dari Rp 181.908 per $\mathrm{m}^{3}$ menjadi Rp 141.370 per $\mathrm{m}^{3}$ atau menurun sebesar $22,3 \%$. Laba yang diperoleh merupakan laba bersih (biaya bunga dan pajak telah dibayarkan) sehingga penurunan laba yang diperoleh dipandang tidak akan mengguncangkan kegiatan pengelolaan hutan. Hasil kajian Sarsito et al. (2003) menyimpulkan pungutan DR sebesar USD 16 per $\mathrm{m}^{3}$ dan PSDH sebesar USD 6,25 per $\mathrm{m}^{3}$ dipandang masih terlalu rendah.

Tabel 5. Implikasi perubahan tarif PSDH terhadap laba perusahaan contoh di Kalimantan Timur.

Table 5. Implication of PSDH tariff change on profit of sample company in East Kalimantan.

\begin{tabular}{|c|c|c|c|c|c|}
\hline No. & Uraian (Items) & $\mathrm{Rp} / \mathrm{m}^{3}$ & $\begin{array}{c}\text { Harga patokan } \\
\text { PSDH tidak } \\
\text { berubah (Standard } \\
\text { price at PSDH not } \\
\text { change) } \\
\left(\mathrm{Rp} / \mathrm{m}^{3}\right) \\
\end{array}$ & $\begin{array}{l}\text { Harga patokan } \\
\text { PSDH berubah } \\
\text { (Standard price at } \\
\text { change PSDH) } \\
\left(\mathrm{Rp} / \mathrm{m}^{3}\right)\end{array}$ & $\begin{array}{c}\% \\
\text { perubahan } \\
\text { (Change) }\end{array}$ \\
\hline A & $\begin{array}{l}\text { Produksi kayu bulat (Log } \\
\text { production) }\end{array}$ & & & & \\
\hline B & $\begin{array}{l}\text { Harga kayu bulat di TPn ( } \log \\
\text { price at forest gate) }\end{array}$ & $1.128 .318,2$ & & & \\
\hline \multirow[t]{8}{*}{$\mathrm{C}$} & $\begin{array}{l}\text { Komponen biaya pengelolaan hutan (Cost } \\
\text { component of forst management) }\end{array}$ & & & & \\
\hline & 1. Biaya produksi kayu bulat (Log production ce & & 219.567 & 219.567 & 0 \\
\hline & 2. Biaya perbaikan stok hutan (Forest stock im & ent cost) & 22.059 & 22.059 & 0 \\
\hline & $\begin{array}{l}\text { 3. Biaya kelola lingkungan dan sosial (Manag } \\
\text { of environmental and social cost) }\end{array}$ & & 11.410 & 11.410 & 0 \\
\hline & 4. Biaya sarpras (Cost of facilities and infrastruct & & 295.948 & 295.948 & 0 \\
\hline & 5. Biaya umum dan administrasi (General and & iistration cost) & 154.314 & 154.314 & 0 \\
\hline & 6. Biaya kewajiban kepada negara (forest prod & & 243.112 & 277.900 & 14,3 \\
\hline & Total biaya (Total cost) $(1 \mathrm{sd} 6)$ & & 946.410 & 981.198 & 3,7 \\
\hline $\mathrm{D}$ & Laba/rugi (Profit/ loss) & & 181.908 & 147.120 & $-19,1$ \\
\hline
\end{tabular}

Tabel 6. Implikasi perubahan tarif DR dan PSDH terhadap laba perusahaan contoh di Kalimantan Timur. Table 6. Implication of DR and PSDH tariff change on profit of sample company in East Kalimantan.

\begin{tabular}{|c|c|c|c|c|c|}
\hline No. & Uraian (Items) & $\mathrm{Rp} / \mathrm{m}^{3}$ & $\begin{array}{l}\text { DR dan PSDH } \\
\text { tidak berubah } \\
\text { (DR and PSDH } \\
\text { was not changed) } \\
\left(\mathrm{Rp} / \mathrm{m}^{3}\right) \\
\end{array}$ & $\begin{array}{c}\text { DR dan PSDH } \\
\text { berubah (DR and } \\
\text { PSDH was changed) } \\
\left(\mathrm{Rp} / \mathrm{m}^{3}\right)\end{array}$ & $\begin{array}{c}\% \\
\text { perubahan } \\
\text { (Change) }\end{array}$ \\
\hline A & $\begin{array}{l}\text { Produksi kayu bulat }(\log \\
\text { production) }\end{array}$ & & & & \\
\hline B & $\begin{array}{l}\text { Harga kayu bulat di TPn } \\
\text { (Log price at forest gate) }\end{array}$ & 1.128 .318 & & & \\
\hline \multirow[t]{8}{*}{ C } & $\begin{array}{l}\text { Komponen biaya pengelolaan hutan (Cost } \\
\text { component of forst management) }\end{array}$ & & & & \\
\hline & $\begin{array}{l}\text { 1. Biaya produksi kayu bulat (Log production } \\
\cos t)\end{array}$ & & 219.567 & 219.567 & 0 \\
\hline & $\begin{array}{l}\text { 2. Biaya perbaikan stok hutan (Forest stock } \\
\text { improvement stock) }\end{array}$ & & 22.059 & 22.059 & 0 \\
\hline & $\begin{array}{l}\text { 3. Biaya kelola lingkungan dan sosial } \\
\text { (Management of enviromental and social cost) }\end{array}$ & & 11.410 & 11.410 & 0 \\
\hline & $\begin{array}{l}\text { 4. Biaya sarpras (Cost of facilities and } \\
\text { infrastructure) }\end{array}$ & & 295.948 & 295.948 & 0 \\
\hline & $\begin{array}{l}\text { 5. Biaya umum dan administrasi (General and } \\
\text { administration cost) }\end{array}$ & & 154.314 & 154.314 & 0 \\
\hline & $\begin{array}{l}\text { 6. Biaya kewajiban kepada negara (Forest product } \\
\text { royalty) }\end{array}$ & & 243.112 & 283.650 & 16,7 \\
\hline & Total biaya (Total cost) $(1 \mathrm{sd} 6)$ & & 946.410 & 986.948 & 4,3 \\
\hline $\mathrm{D}$ & Laba/rugi (Profit/loss) & & 181.908 & 141.370 & $-22,3$ \\
\hline
\end{tabular}




\section{B. Implikasi Perubahan Tarif DR dan PSDH terhadap PNBP Sektor Kehutanan}

Implikasi perubahan tarif DR dan PSDH terhadap PNBP disajikan pada Tabel 7. Pada Tabel 7 terlihat bahwa jika tarif DR meningkat USD 0,50 per $\mathrm{m}^{3}$, maka PNBP dari DR akan meningkat $22,2 \%$, sedangkan jika harga patokan PSDH ditetapkan di TPn $\left(\mathrm{Rp} 1.128 .318 / \mathrm{m}^{3}\right)$, maka PNBP dari PSDH akan meningkat 44,6\%. Secara keseluruhan persentase kenaikan PNBP akibat perubahan tarif DR dan PSDH tersebut akan mencapai 29,7\%, suatu kenaikan yang signifikan.

Menggunakan kriteria laba pemegang ijin
UPHHK-HA akan terguncang jika perubahan tarif menyebabkan laba berkurang sampai 50\%, maka perubahan tarif DR (yang naik USD $\left.0,50 / \mathrm{m}^{3}\right)$ terlihat belum mengguncangkan laba $(-3,2 \%)$. Demikian pula dengan penetapan harga patokan PSDH di TPn $\left(\mathrm{Rp} 1.128 .318 / \mathrm{m}^{3}\right)$ juga belum mengguncangkan laba pemegang ijin UPPHHK-HA (-19,1\%). Perubahan kedua tarif tersebut secara berbarengan juga belum menyebabkan laba pemegang ijin terguncang secara signifikan (-22,3\%). Meskipun akibat perubahan tarif DR dan PSDH, laba menjadi menurun namun penurunannya belum sampai menimbulkan kerugian.

Tabel 7. Implikasi perubahan tarif DR dan PSDH terhadap Penerimaan Negara Bukan Pajak pada kasus perusahaan contoh di Kalimantan Timur.

Table 7. Implication of DR and PSDH tariff change on non-tax state revenue of sample company in East Kalimantan.

\begin{tabular}{|c|c|c|c|c|c|c|}
\hline \multirow[b]{2}{*}{ No. } & \multirow[b]{2}{*}{ Uraian (Items) } & \multirow[b]{2}{*}{$\mathrm{m}^{3}$} & \multirow[b]{2}{*}{$\mathrm{Rp} / \mathrm{m}^{3}$} & \multicolumn{3}{|c|}{ Penerimaan PNBP (PNBP revenue) } \\
\hline & & & & $\begin{array}{c}\text { Sebelum } \\
\text { perubahan tarif } \\
(\text { Before tariff } \\
\text { change) }(\mathrm{Rp})\end{array}$ & $\begin{array}{c}\text { Setelah perubahan } \\
\text { tariff (After tariff } \\
\text { change) }(\mathrm{Rp})\end{array}$ & $\begin{array}{c}\% \\
\text { perubahan } \\
\text { (Change) }\end{array}$ \\
\hline A & $\begin{array}{l}\text { Produksi kayu bulat } \\
\text { (Log production) }\end{array}$ & $58.289,27$ & & & & \\
\hline B & $\begin{array}{l}\text { Harga kayu bulat di TPn } \\
\text { (Log price at forest gate) }\end{array}$ & & 1.128 .318 & & & \\
\hline \multirow[t]{4}{*}{$\mathrm{C}$} & Jenis pungutan (Types of & tariff) & & & & \\
\hline & 1. DR & & & 9.051 .237 .473 & 11.060 .388 .983 & 22,2 \\
\hline & 2. $\mathrm{PSDH}$ & & & 4.549 .123 .859 & 6.576.884.312 & 44,6 \\
\hline & Jumlah (Total) & & & 13.600 .361 .332 & 17.637 .273 .295 & 29,7 \\
\hline
\end{tabular}

Tabel 8. Maksimum kenaikan tarif DR dan PSDH pada kasus perusahaan contoh di Kalimantan Timur. Table 8. Maximum increase in DR and PSDH tariff on sample company in East Kalimantan.

\begin{tabular}{|c|c|c|c|c|}
\hline \multirow[t]{2}{*}{ No. } & \multirow{2}{*}{$\begin{array}{l}\text { Skenario kebijakan } \\
\quad \text { (Policy scenario) }\end{array}$} & $\begin{array}{l}\text { Nilai dasar } \\
\text { (Base value) }\end{array}$ & $\begin{array}{l}\text { Maksimum kenaikan } \\
\text { (Maximum increase) }\end{array}$ & Laba (Profit) \\
\hline & & DR & DR & $\mathrm{Rp} / \mathrm{m}^{3}$ \\
\hline 1 & $\begin{array}{l}\text { Jika PSDH tidak berubah (If PSDH tariffis } \\
\text { changed)(Permendag Nomor 8/M-DAG/ } \\
\text { PER/2/2007), maka tarif DR dapat dinaikkan } \\
\text { (DR tariff can be increased }\end{array}$ & USD $0,50 / \mathrm{m}^{3}$ & USD $15,8 / \mathrm{m}^{3}$ & 0 \\
\hline \multirow[t]{2}{*}{2} & $\begin{array}{l}\text { Jika tarif PSDH berubah (Peraturan baru: } 10 \% \\
\text { dari harga di TPn), maka tarif DR dapat dinaikkan } \\
\text { (If PSDH tariffis changed (10\% from logpond price) DR } \\
\text { tariff can be increased }\end{array}$ & USD $0,50 / \mathrm{m}^{3}$ & USD $12,8 / \mathrm{m}^{3}$ & 0 \\
\hline & & PSDH & PSDH & $\mathrm{Rp} / \mathrm{m}^{3}$ \\
\hline 3 & $\begin{array}{l}\text { Jika tarif DR tidak berubah (If DR tariff is not } \\
\text { changed) (PP59/1998), maka PSDH dapat } \\
\text { dinaikkan (PSDH tariff can be increased) }\end{array}$ & $10 \%$ & $23 \%$ & 0 \\
\hline 4 & $\begin{array}{l}\text { Jika DR naik USD } 0,5 \text { per } \mathrm{m}^{3} \text {, maka tarif PSDH } \\
\text { dapat dinaikkan (If DRis increased up to 0,5 } \$ \text { USD } \\
\text { per } \mathrm{m}^{3}, \text { PSDH can be increased) }\end{array}$ & $10 \%$ & $22,5 \%$ & 0 \\
\hline
\end{tabular}


Tabel 8 menyajikan hasil simulasi pengaruh perubahan tarif DR dan PSDH terhadap laba pemegang ijin UPPHHK-HA. Pada Tabel 8 terlihat bahwa jika hanya tarif DR yang diubah sementara PSDH tidak berubah, maka hasil simulasi (asumsi: USD $1,00=\mathrm{Rp} 11.500$ ) menunjukkan bahwa pemegang ijin akan menerima laba nol rupiah jika DR dinaikkan dari USD 0,50 per $\mathrm{m}^{3}$ menjadi USD 15,8 per $\mathrm{m}^{3}$. Jika hanya tarif PSDH yang berubah sementara tarif DR tidak berubah, maka hasil simulasi (asumsi: USD $1,00=\mathrm{Rp}$ 11.500) menunjukkan bahwa pemegang ijin akan menerima laba nol rupiah jika persentase tarif PSDH dinaikkan sebesar 13\% menjadi 23\% dari sebelumnya $(10 \%)$. Selanjutnya jika tarif PSDH adalah 10\% dari harga di TPn, maka hasil simulasi menunjukkan bahwa pemegang ijin UPHHK-HA akan menerima laba nol rupiah jika tarif DR dinaikkan menjadi USD 12,8 per $\mathrm{m}^{3}$. Jika tarif DR dinaikkan USA 0,50 per $\mathrm{m}^{3}$, maka laba pemegang ijin UPHHK-HA akan nol rupiah jika tarif PSDH dinaikkan dari $10 \%$ menjadi $22,5 \%$.

\section{Potensi PNBP dari Limbah Pembalakan}

Limbah pembalakan dibedakan ke dalam dua kelompok, yaitu: 1) limbah kayu pada batang bebas cabang (BBC) dan (2) limbah kayu di atas BBC. Limbah kayu pada BBC dibedakan ke dalam dua golongan, yaitu: 1) limbah pangkal dan 2) limbah ujung, sedangkan limbah di atas BBC dinamakan limbah ujung. Hasil pengukuran limbah pangkal dan ujung pada BBC disajikan pada Tabel 9 dan Tabel 10, sedangkan limbah di atas BBC pada Tabel 11. Dari ketiga tabel tersebut terlihat bahwa limbah kayu yang ditinggalkan di lokasi penebangan merupakan limbah kayu berbentuk batang kayu ( $\log$ ) yang berdiamater di atas $50 \mathrm{~cm}$ dengan panjang antara 1,7-4 m (Tabel 9 dan Tabel 10) kecuali limbah di atas BBC, yang memiliki rataan diameter ujung dan pangkal berturut-turut $33,91 \mathrm{~cm}$ dan 47,35 cm dengan rataan panjang 3,63 $\mathrm{m}$ (Tabel 11).

Tabel 9 menjelaskan bahwa pada setiap pohon komersial yang ditebang rataan panjang limbah pangkal yang ditinggalkan adalah 1,70 m dengan diamater ujung dan pangkal berturut-turut adalah $79,76 \mathrm{~cm}$ dan $80,05 \mathrm{~cm}$, sementara Tabel 10 menjelaskan bahwa pada setiap pohon komersial yang ditebang rataan panjang limbah ujung yang ditinggalkan adalah $4 \mathrm{~m}$ dengan diameter ujung dan pangkal berturut-turut $50 \mathrm{~cm}$ dan $60 \mathrm{~cm}$. Tabel 11 menjelaskan bahwa pada setiap pohon komersial yang ditebang rataan panjang limbah di atas BBC yang ditinggalkan adalah 3,63 m dengan

Tabel 9. Limbah pangkal pada pohon bebas cabang.

Table 9. Butt waste on clear bole.

\begin{tabular}{llcc}
\hline No & \multicolumn{1}{c}{ Uraian $($ Items $)$} & Nilai rataan $($ Average value $)$ & Deviasi (Deviation) \\
\hline 1 & Diameter pangkal (Diameter on butt $)(\mathrm{cm})$ & 80,05 & 13,06 \\
2 & Diameter ujung $($ Diameter on top) $(\mathrm{cm})$ & 79,76 & 13,44 \\
3 & Panjang $($ Length) $(\mathrm{m})$ & 1,70 & 1,32 \\
4 & Volume $\left(\mathrm{m}^{3}\right)$ & 0,971 & 1,094 \\
\hline
\end{tabular}

Tabel 10. Limbah ujung pada pohon bebas cabang.

Table 10. Top waste on clear bole.

\begin{tabular}{llcc}
\hline No & \multicolumn{1}{c}{ Uraian $($ Items $)$} & Nilai rataan $($ Average value $)$ & Deviasi (Deviation) \\
\hline 1 & Diameter pangkal (Diameter on butt) $(\mathrm{cm})$ & 60 & 12 \\
2 & Diameter ujung $($ Diameter on top) $(\mathrm{cm})$ & 50 & 12 \\
3 & Panjang $($ Length) $(\mathrm{m})$ & 4 & 3 \\
4 & Volume $\left(\mathrm{m}^{3}\right)$ & 0,837 & 0,632 \\
\hline
\end{tabular}

Tabel 11. Limbah kayu di atas pohon bebas cabang.

Table 11. Wood waste above clear bole.

\begin{tabular}{llcc}
\hline No & \multicolumn{1}{c}{ Uraian $($ Items $)$} & Nilai rataan (Average value $)$ & Deviasi (Deviation) \\
\hline 1 & Diameter pangkal (Diameter on butt $)(\mathrm{cm})$ & 47,35 & 9,44 \\
2 & Diameter ujung $($ Diameter on top) $(\mathrm{cm})$ & 33,91 & 4,24 \\
3 & Panjang $($ Length) $(\mathrm{m})$ & 3,63 & 1,38 \\
4 & Volume $\left(\mathrm{m}^{3}\right)$ & 0,266 & 0,30 \\
\hline
\end{tabular}


diameter ujung dan pangkal berturut-turut 33,91 $\mathrm{cm}$ dan $47,35 \mathrm{~cm}$. Total volume kayu limbah pembalakan pada setiap pohon komersil yang ditebang (limbah pada BBC dan di atas BBC) mencapai rataan per pohon sebesar 2,074 $\mathrm{m}^{3}$ (volume limbah pangkal plus limbah ujung plus limbah di atas BBC).

Jumlah limbah tersebut lebih sedikit dibandingkan penelitian Matangaran et al. (2013) yaitu berkisar antara 3,42-3,45 $\mathrm{m}^{3} /$ pohon tetapi lebih besar dibandingkan penelitian Idris et al. (2012) yang hanya berkisar antara $0,99-1,19 \mathrm{~m}^{3} /$ pohon. Penelitian Soenarno (2014) menunjukkan bahwa rataan volume limbah kayu BBC sebanyak 1,395 $\mathrm{m}^{3} /$ pohon terdiri atas limbah kayu berkualitas baik sebanyak $0,357 \mathrm{~m}^{3} /$ pohon $(25,58 \%)$; limbah cacat sebanyak $0,610 \mathrm{~m}^{3} /$ pohon $(43,77 \%)$ dan limbah yang pecah sebanyak $0,438 \mathrm{~m}^{3} /$ pohon $(30,65 \%)$. Terjadinya perbedaan jumlah limbah kayu diduga diakibatkan oleh beberapa faktor di antaranya kondisi topografi, dominasi jenis pohon, teknik pembagian batang, dan cara pengeluaran kayu dari petak tebang menuju ke TPn. Dari sisi ekonomi, pembedaan tarif DR dapat diharapkan menaikkan PNBP dan menekan limbah pembalakan (Soedomo, 2013).

Pada RKT tahun 2013, hasil ITSP perusahaan contoh menunjukkan jumlah pohon ditebang sebanyak 9.787 pohon, yang terdiri dari 2.448 pohon berasal dari hutan produksi (HP) dan 7.339 pohon dari hutan produksi terbatas (HPT). Dengan mempertimbangkan limbah pembalakan yang dapat dimanfaatkan sebesar $2 \mathrm{~m}^{3}$ per pohon, maka setiap tahun diperkirakan akan tersedia $4.896 \mathrm{~m}^{3}$ limbah kayu di HP dan $14.678 \mathrm{~m}^{3}$ di HPT atau total sebesar $19.574 \mathrm{~m}^{3}$ per tahun, suatu jumlah yang relatif besar. Dengan mengenakan DR untuk limbah pembalakan sebesar USD 2 per $\mathrm{m}^{3}$ akan diperoleh tambahan PNBP perusahaan contoh sebesar USD 39.148 per tahun.

Besarnya limbah pembalakan yang dapat dimanfaatkan maka disarankan perlunya kebijakan untuk mendorong pemanfaatannya secara lebih efektif dan efisien. Sejauh ini terdapat dua industri yang telah memanfaatkan limbah pembalakan, yaitu PT. Erna Djuliawati dan PT. Sarpatim, keduanya beroperasi di Kabupaten Seruan, Kalimantan Tengah. Kapasitas produksi PT. Erna Djuliawati adalah $12.000 \mathrm{~m}^{3}$ per tahun, sedangkan PT. Sarpatim adalah $38.000 \mathrm{~m}^{3}$ per tahun untuk veneer dan $12.000 \mathrm{~m}^{3}$ per tahun untuk kayu gergajian (komunikasi pribadi, 2014). Pemanfaatan selain untuk veneer dan kayu gergajian perlu didorong sejauh teknologi tersedia dan bermanfaat bagi perkembangan lingkungan, sosial dan ekonomi masyarakat setempat. Ini selaras dengan sistem dan standar sertifikasi Pengelolaan Hutan Produksi Lestari (PHPL) yang mendorong unit manajemen menerapkan kebijakan zero waste sebagai salah satu upaya meningkatkan viabilitas ekonomi perusahaan.

\section{KESIMPULAN DAN SARAN}

\section{A. Kesimpulan}

Komposisi biaya pengelolaan hutan mengindikasikan kelestarian hutan dalam jangka panjang cenderung terganggu karena biaya perbaikan stok hutan, biaya kelola lingkungan dan sosial relatif sangat kecil dibanding biaya pemungutan hasil hutan, biaya sarpras dan kewajiban kepada negara. Meskipun kenaikan tarif DR (naik USD 0,5 per m³) dan PSDH (10\% dari harga di TPn) akan meningkatkan perolehan PNBP dari perusahaan (29,7\% dari sebelum perubahan $\mathrm{Rp}$ 13,6 miliar) namun perolehan laba perusahaan akan menurun (-22,3\% dari sebelum perubahan Rp 181.908 per $\left.\mathrm{m}^{3}\right)$.

Perubahan tarif yang terjadi pada PSDH pengaruhnya terhadap perolehan laba perusahaan lebih sensitif dibanding perubahan tarif yang terjadi pada DR. Perubahan tarif yang terjadi pada PSDH adalah harga patokan PSDH ditetapkan di TPn, sedangkan perubahan tarif DR yang terjadi adalah tarif DR dinaikkan sebesar USD 0,5 per $\mathrm{m}^{3}$. Perubahan tarif DR tersebut menyebabkan perolehan laba perusahaan menurun sebesar 3,2\%, sedangkan perubahan harga patokan $\mathrm{PSDH}$ menyebabkan perolehan laba perusahaan menurun sebesar 19,1\%.

Jika tarif PSDH tidak berubah (Permendag Nomor 8/M-DAG/PER/2/2007) dan hanya tarif DR yang dinaikkan, maka kenaikan tarif DR yang maksimal adalah USD 15,8 per $\mathrm{m}^{3}$ tapi jika tarif PSDH berubah (10\% dari harga di TPn), maka kenaikan tarif DR yang maksimal adalah USD 12,8 per $\mathrm{m}^{3}$. Jika tarif DR tidak berubah dan hanya tarif PSDH yang dinaikkan, maka kenaikan tarif PSDH yang maksimal adalah 23\% dan jika tarif DR 
dinaikkan sebesar USD 0,5 per $\mathrm{m}^{3}$, maka kenaikan tarif PSDH yang maksimal adalah hanya 22,5\% dari sebelumnya $(10 \%)$.

Potensi limbah kayu pembalakan sebagai sumber tambahan PNBP sektor kehutanan adalah tinggi. Limbah pembalakan (sawlog, veneerlog) dari setiap pohon yang ditebang adalah $2 \mathrm{~m}^{3}$ per pohon dan di perusahaan contoh setiap tahun diperkirakan tersedia $4.896 \mathrm{~m}^{3}$ limbah kayu di HP dan $14.678 \mathrm{~m}^{3}$ di HPT atau total $19.574 \mathrm{~m}^{3}$. Namun perusahaan contoh belum memanfaatkan limbah pembalakan yang jika tarif DR limbah pembalakan adalah USD 1 per $\mathrm{m}^{3}$ berpotensi menghasilkan tambahan PNBP sebesar USD 19.574 per tahun.

\section{B. Saran}

Mempertimbangkan biaya perbaikan stok hutan, biaya kelola lingkungan dan sosial relatif sangat kecil dibanding biaya pemungutan hasil hutan, biaya sarpras dan kewajiban kepada negara, maka kebijakan perubahan tarif DR dan PSDH sebagai komponen biaya kewajiban kepada negara perlu mempertimbangkan kepekaan perubahannya terhadap perolehan laba perusahaan. Mengingat kenaikan tarif PSDH lebih sensitif dibanding kenaikan tarif DR, kebijakan kenaikan tarif DR (USD 0,50 per $\mathrm{m}^{3}$ ) dapat langsung diberlakukan, sementara penetapan harga kayu bulat di TPn perlu didasarkan pada suatu metode penetapan yang rasional.

Potensi limbah pembalakan yang tinggi (19.574 $\mathrm{m}^{3}$ per tahun) memberikan kesempatan pemanfaatannya dan pengenaan pungutannya. Namun selama DR dan PSDH telah dibayar oleh perusahaan, maka pengenaan pungutan terhadap limbah pembalakan tidak diperlukan, sebaliknya pengenaan pungutan terhadap limbah perlu dikenakan ketika limbah pembalakan tidak dimanfaatkan. Perubahan tarif DR dan PSDH perlu mempertimbangkan besarnya limbah pembalakan di hutan. Semakin tinggi limbah pembalakan yang ditinggalkan di hutan semakin tinggi tambahan DR dan PSDH yang seharusnya dikenakan.

\section{DAFTAR PUSTAKA}

Astana, S. \& Siran, S. (2011). Evaluasi tarif PSDH kayu hutan alam. Policy Brief, 5(5).
Astana, S. (2003). Dampak kebijakan pengu-rangan subsidi harga bahan bakar minyak terbadap kinerja industri hasil butan kayu dan kelestarian butan. (Tesis). Institut Pertanian Bogor, Bogor.

Direktorat BIKPHH (2013). Revisi PP no. 59 tahun 1998 tentang tarif atas jenis PNBP yang berlaku di Departemen Kebutanan dan Perkebunan. Bahan presentasi pada pembahasan revisi PP 59/1998 tentang PNBP dari PSDH dan DR, Gedung Manggala Wanabakti, 9 April 2013. Jakarta: Direktorat BIKPHH.

Direktorat Jenderal Bina Usaha Kehutanan (2013). Pembahasan revisi PP nomor 59 tahun 1998 tentang tarif atas jenis PNBP yang berlaku pada Departemen Kebutanan dan Perkebunan, Gedung Manggala Wanabakti, 18 Juni 2013. Jakarta: Direktorat Jenderal Bina Usaha Kehutanan.

Gray, J. W. (1983). Forest revenue systems in developing countries: their role in income generation and forest management strategies. (FAO Forestry Paper 43). Food and Agriculture Organization of the United Nations. Diunduh dari http: //www.fao.org/docrep/015/an781e/an781e 00.pdf.(16 Juli 2014).

Greennomics Indonesia \& Indonesia Corruption Watch (2004). Pungutan usaha kayu: Evolusi terhadap mekanisme perbitungan, pemungutan, dan penggunaan pungutan usaha kayu. (Kertas kerja No. 7). Diunduh dari http://www .greenomics.org/docs/wp07.pdf.(8 juli 2014).

Idris, M.M., Sukanda \& Soenarno (2012). Teknik tree length logging di hutan alam produksi lahan kering. (Laporan Hasil Penelitian). Bogor: Pusat Penelitian dan Pengembangan Keteknikan Kehutanan dan Pengolahan Hasil Hutan.

Karsenty, A. (2010). Forest taxation regime for tropical forests: lessons from Central Africa. International Forestry Review, 12(2), 121129. Diunduh dari http://www .ingentaconnect.com / content/cfa/ ifr/2010/00000012/00000002/art0000? crawler $=$ true\&mimetype $=$ application $/$ pdf. (16 Juli 2014).

Kartodihardjo, H. \& Soedomo, S. (2013). Tinjanan tarif DR kayu diameter $30-49 \mathrm{~cm}$. Bahan presentasi pada pembahasan revisi PP 
59/1998 tentang PNBP dari PSDH dan DR, Gedung Manggala Wanabhakti, 9 April 2013. Jakarta: Direktorat BIKPHH.

Keputusan Presiden nomor 29 tahun 1990 tentang Dana Reboisasi.

Keputusan Presiden nomor 35 tahun 1980 tentang Dana Jaminan Reboisasi dan Permudaan Hutan Areal Hak Pengusahaan Hutan.

Matangaran, J.R., Partiani, T., \& Purnamasari, D.R. (2013). Faktor eksploitasi dan kuantifikasi limbah kayu dalam rangka peningkatan efisiensi pemanenan hutan alam. Jurnal Bumi Lestari, 13(2), 384-393.

Peraturan Menteri Perdagagangan No. 8/MDAG/PER/2/2007 tentang Penetapan Harga Patokan untuk Perhitungan PSDH Kayu dan Bukan Kayu.

Peraturan Pemerintah No. 12 tahun 2014 tentang Jenis dan Tarif atas Jenis Penerimaan Negara Bukan Pajak yang Berlaku pada Kementerian Kehutanan.

Peraturan Pemerintah No. 22 tahun 1997 tentang Jenis dan Penyetoran Penerimaan Negara Bukan Pajak: Lampiran IIA angka 9.

Peraturan Pemerintah No. 51 tahun 1998 tentang Provisi Sumber Daya Hutan.

Peraturan Pemerintah No. 52 tahun 1998 tentang Perubahan Peraturan Pemerintah No. 22 tahun 1997 tentang Jenis dan Penyetoran Penerimaan Negara Bukan Pajak.

Peraturan Pemerintah No. 59 tahun 1998 tentang Tarif atas Jenis PNBP yang Berlaku pada Departemen Kehutanan dan Perkebunan.

Peraturan Pemerintah No. 64 tahun 1957 tentang Penyerahan Sebagian dari Urusan Pemerintah
Pusat di Lapangan Perikanan Laut, Kehutanan dan Karet Rakyat kepada Daerah-daerah Swatan-tra Tingkat I.

Peraturan Pemerintah No. 74 tahun 1999 tentang Perubahan Peraturan Pemerintah No. 59 tahun 1998 tentang Tarif atas Jenis PNBP yang Berlaku pada Departemen Kehutanan dan Perkebunan.

Peraturan Pemerintah No. 92 tahun 1999 tentang Perubahan Kedua Peraturan Pemerintah No. 59 tahun 1998 tentang Tarif atas Jenis PNBP yang Berlaku pada Departemen Kehutanan dan Perkebunan.

Saputra, U.S. (1995). Sistem penetapan pungutan hasil butan kayu bulat oleh pemerintah di areal HPH: Suatu analisis kebijakan ekonomi kebutanan (Disertasi). Insitut Pertanian Bogor, Bogor.

Sarsito, A., Warsito, S., Brown, D., Boccucci, M., \& Tuli, P. (2003). Indonesia background paper. In World Bank (Eds.), Proceedings of the international workshop on reforming forest fiscal systems to promote poverty reduction, and sustainable forest management (pp. 59-67). Washington, D.C: World Bank.

Soedomo, S. (2013). Double dividend from tariff differentiation of reforestation fund. Journal of Tropical Forest Management, 19(2), 163- 67.

Soenarno. (2014). Efisiensi pembalakan dan kualitas limbah pembalakan di hutan tropika pegunungan: Studi kasus di IUPHHK-HA PT. Roda Mas Timber Kalimantan. Jurnal Penelitian HasilHutan, 32(1), 45-61.

Undang Undang No. 20 tahun 1997 tentang Penerimaan Negara Bukan Pajak.

Undang Undang No. 41 tahun 1999 tentang Kehutanan. 